\title{
THE IMPLICATIONS OF PROPAGANDA AS A SOCIAL INFLUENCE STRATEGY
}

\author{
Maria-Lucia RUSU \\ rusu.maria@armyacademy.ro \\ Ramona HERMAN \\ herman.ramona@armyacademy.ro \\ “NICOLAE BĂLCESCU” LAND FOCES ACADEMY, SIBIU, ROMANIA
}

\begin{abstract}
In contemporary society, propaganda has a major impact due to the new technologies in the media (satellite television, the Internet) that ensure the rapid and instant transmission of information, thus expanding the audience. The concept of propaganda acts systematically in support of a doctrine, in order to persuade a large mass of individuals. It is generally associated with a negative action, considered to be reprehensible, and this is the consequence of the attempts that various totalitarian regimes have manifested abusively. Basically, propaganda is a conscious communication act with a political and revolutionary character representing a strategy of social influence. The element of difference is misinformation. Thus, this concept can be one of integration and consolidation of the society or, on the contrary, it can be a factor of agitation.
\end{abstract}

\section{KEYWORDS:}

Propaganda, misinformation, manipulation, persuasion, strategy, social influence

\section{Introduction}

In times of peace, political propaganda is active and manifests its forms in all its aspects. Positive propaganda is for the benefit of society. In this sense, we have numerous examples in Romania's history, from the Unification of the Romanian Principalities, to the Great Union on December $1^{\text {st }}$, 1918 , or Romania's entry into NATO. Propaganda action should not be condemned and blamed, as a habit of bias. It is true that mankind has often faced a perverse and wicked propaganda, with devastating effects during crises and war. The leaders and the winners were those who used negative propaganda, and those who suffered were the victims of this propaganda.

Călin Hentea defines the concept of propaganda as "planned persuasive communication actions, supported by a sponsor with the ultimate goal of influencing and even modifying the attitudes and behaviors of a target audience selected to satisfy sponsor's political interests, using falsified information and arguments, 
partially true, distorted and exclusive, alongside true ones and accompanied by various forms of coercion and censorship" (Hentea, 2008).

Propaganda discourse presents a definite tone in expressing messages that exclude contradiction and nuance. This act of public communication is a conscious action, manifested by an individual or a legal entity with certain goals. Propaganda should not be perceived as a subversive or negative act, it has a political and revolutionary character as a form of mass influence of public opinion.

Propaganda attempts to form perceptions by introducing "specific images and languages (slogans, posters, symbols), for example, in January 1991, the military operation The Shield of the Desert was renamed Desert Storm, as it was intended to form a more engaging perception and more warlike (Storm), instead of a protective perception (Shield). Other trendy slogans in this context, which have fueled the media's advancement in rival camps, have led Saddam Hussein to address US President George Bush as Devil Bush, as many US newspapers titled the name of the Iraqi president in a rewrite like Saddam = SADdam. Such linguistic clichés aimed at shaping the perception of the Americans in seeing Saddam as an unsated person, as he was often evoked in the overseas press, and, in the case of the Arabs, in perceiving Saddam as a heroic Islamic leader" (Gavreliuc, 2007, p. 188). The main purpose of propaganda is to target behaviors, for example: "During the Gulf War, strategies to discourage the adverse camp have been devised. Thus, the US Army's Fourth Corps of Psychological Operations spread 29 million manifests in Iraq and organized the Voice of the Gulf radio station broadcasting the testimonies of Iraqi prisoners happy and freed from tyranny along with prayers from the Koran. The effects of such strategies were considerable: through subsequent evaluations it was demonstrated that over $75 \%$ of target subjects were influenced by such messages" (Gavreliuc, 2007, p. 188).

Looking retrospectively, the term "propaganda" was introduced by Catholics in 1622 through a Vatican structure designed to hinder Protestant reform. Then, Emperor Caesar approached this issue when he sent to Rome the reports of the destruction of Gali "De bello galico" or Martin Luther when he promoted his antipapal theses.

If we restrict the area of analysis to Romanian space, we find that Romania has started a propaganda program for the union with Transylvania under the Occupation of the Austro-Hungarian Empire and has not forgotten Bessarabia which was under Russian occupation. Under these conditions, we find the positive and constructive involvement of the concept of propaganda, a voluntary and patriotic form. Another model of propaganda with emotional and patriotic accents was demonstrated by Queen Maria in her diplomatic work at European level to promote Romanian interests and to recognize the identity of her own people. The most beneficial form of propaganda is the cultivation of patriotism that infuses generations, communities and social groups with the values and social norms concluding to the society in question, thus preserving the national and cultural identity of the sovereign state through continuity.

Until the end of the First War, propaganda was part of the political activity; at that time the technical means of communication and dissemination had developed, such as the telegraph and the written press; they provided wide access to information to both citizens and soldiers in the battlefield. The hyperbolism of propaganda, especially Britain's Grewe House during the war on the Germans, or Wellington House propaganda to engage the United States in conflict, excluded it from the matter-of-course of political activity. And then, Hitler and Stalin came to stigmatize propaganda forever. 
After the war, propaganda was given different names, as Călin Hentea believes: in the army it was called "psychological operations - PSYOPS" and later "information operations - INFO OPS"; in politics it was called strategic communication or political communication; in the institutional sphere it was called public relations and public affairs; in the commercial space we find it in the form of advertising and in the diplomatic space is called public diplomacy.

\section{Classification of propaganda}

Propaganda is classified as: white propaganda, in which the information issuer is declared, assumed; gray propaganda, where the author of the messages is unknown and black propaganda, in which the declared messenger is not the real one.

White propaganda delivers accurate information from an acclaimed actor, with scrupulous accuracy. The message is aimed at credibility in the expectation horizon of the audience, to the consolidation of a future influence. An example is the messages of the Free Europe Radio during the Cold War.

In black propaganda, the issuer is fake and sends untrue messages, and the basic element is a lie. The existence of this form depends on the context pressure and the receiver's decision to accept the credibility of the source. A demonstration example was the English New England Broadcasting Station, which was under the command of the Nazis. This radio station broadcasted news that morally affected the soldiers.

The gray propaganda is the most common, it penetrates rapidly in all environments and is at the limit between white and black propaganda. The source of gray propaganda may or may not be known, and the precision of information is uncertain.

\section{Propaganda in peacetime}

In this respect, French sociologist Jacques Ellul in his work Propagandes classified propaganda during peacetime as: propaganda of integration and propaganda of agitation.

Integration propaganda characterizes evolving states with the aim of establishing and consolidating society. The individual adapts and complies with the rules of everyday life within the limits set and accepted by the rules. This type of propaganda is long lasting, less obvious, even subtle. An example is metropolitan propaganda, representative of the American lifestyle, from everyday conversations to talk shows.

In opposition to the propaganda of integration is the agitation propaganda, specific to times of crisis and war, which aims to revolt the population against the system or mobilize it against the enemy. The agitation propaganda action strategies are of a rational, emotional nature that stimulates primary instincts and hatred. Elements that distort information such as lie, hyperbolism, categorical and imperative tone are used.

\section{Propaganda tools}

Propaganda uses certain tools for the public to achieve its own goals. Misinformation is a basic tool of black propaganda, through which false information is emitted. It is a mass communication where the information is of a false nature. The basis of the misinformation is lying. Richard Shultz and Roy Godson define misinformation as a set of false, erroneous, incomplete information that is directed to a target group that represents an individual, group or country (Shultz \& Godson, 1984, p. 41).

The misinformation process includes operations of determining and knowing the target, setting goals, elaborating false messages, and selecting the channel to transmit the message to obtain the feedback. This process is conceived by a communication institution: governments, social, political, economic, intelligence entities, these can be victims or promoters of misinformation. The most targeted audience is the population of a state. 
From a linguistic point of view, the term misinformation comes from English "disinformation" and the Russian "dezinformatsia", which is the name of a division of the KGB responsible for black propaganda.

The act of misinformation includes the subject of misinformation and its scope of action, the message consisting of gross, falsified and deformed information, namely misinformation, the moment of launching the plan and the mode of action and the transmitters that will spread and amplify the message (influential people, journalists, social organizations, mass media means of information).

Vladimir Volkoff places the misinformation between intrusion and influence, saying misinformation is systematic, professional, appealing to the media and adhering to public opinion. Misinformation works only when targeting large masses of individuals, using crowd dynamics, because a restricted group can easily identify distorted information. In this sense, the misinformation action takes a long time and is based on the unconscious involvement of the population. The concept's techniques are diverse and are used in combination, such as misinformation by: word (when using labels, meaning blaming and vilification of a character); number (use and manipulation of statistics to decrease or amplify the importance of an event); repetition (highlighting a crowd message through advertising or political campaigns); rumor (where truncated information is emitted, without the possibility of verifying it); clichés (information brings elements that are close to the beliefs of the target); images (the use of television in the diffusion of distorted information). From the point of view of mechanisms of activating communication, there are two models of misinformation as a process of social communication (Smith, 1989):

1. The defective source model in which propagandist $\mathrm{P}$ proposes a $\mathrm{P} 1$ apparent source of message $\mathrm{M}$. The receiver perceives the information as if it came from P1 and does not identify the authentic propagandist $\mathrm{P}$.

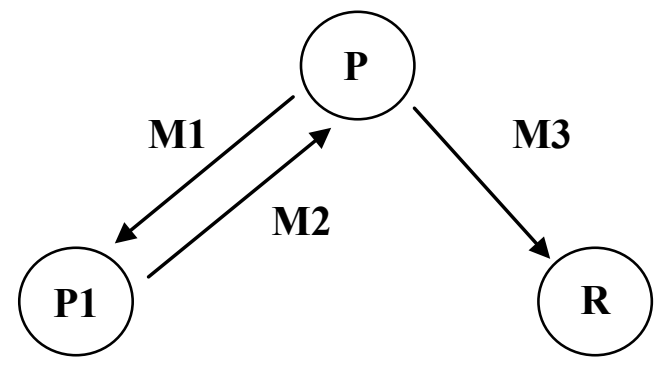

Figure no. 1 Defective source model

(Source: O’Donnell \& Jowett, 2012, p. 25)

2. The legitimizing source model in which propagandist $\mathrm{P}$ secretly produces the M1 message, in a legitimate source P2. The M2 message is retransmitted by the propagandist transmitter $\mathrm{P}$ and transmitted to the $R$ receiver in the form of $M 3$. $\mathrm{P} 2$ legitimizes the message and hides the real propagandist $\mathrm{P}$.

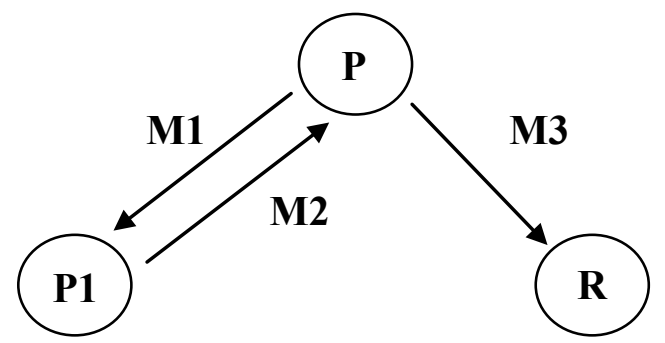

Figure no. 2 Legitimizing source model (Source: O’Donnell \& Jowett, 2012, p. 26)

The term "sub-propaganda" is part of the same social influence strategy and was brought to the foreground by L.W. Doob (1948). In this case, the propagandist disseminates an unfamiliar doctrine over a long period of time and creates " a permissive frame of thought in the audience, in order to accept the doctrine" (Gavreliuc, 2007, p. 192). The action of the sub-propaganda keeps open the attention until it provides the information for the desired purpose. Examples of this are: TV news, press, cultural programs, books, exhibitions, films and seminars. The basic 
element is receptivity, which provides a positive image of the possible propagandist.

\section{Strategy of action and analysis of propaganda}

The promoter uses a series of strategies to achieve effective influence. These strategies consist of: concealing the purpose; hiding identity; the control of the circulation of information (only the necessary messages are provided, through the control of the media and the presentation of the distorted information as coming from a credible source) and the management of public opinion (aiming to manipulate the opinion after a predetermined strategy) (Gavreliuc, 2007, p. 194).

\section{Censorship}

Over time, propaganda has used censorship in many moments. The censorship action involves stopping the dissemination of information to the population, by a control group, so censorship makes the information secret. In the situation where there is a monopoly, the propagandist declares censorship of a contrary opinion. The only actor on the social scene will have the desired and long-sought success, succeeding with ease in imposing its ideology. An example of this is the
Communist propaganda in Romania, which set up a fierce censure to be able to hold the monopoly.

If the Romanians or other peoples tormented by the socialist power had access to information, mobility, culture and freedom, their destiny would have been different. Any act of censorship is an act of propaganda, because disapproval, condemnation and prohibition of another contrary opinion also mean the promotion of one's own vision (T,urlea, 2011).

\section{Related concepts}

In social communication there are concepts that are interconnected, overlapping or sometimes confusing, such as propaganda, manipulation, misinformation and persuasion. Propaganda intersects tangentially with all these concepts. Manipulation is often confused with propaganda, in the sense that the persuader is not aware of being influenced. It is worth underlining the subtle or even Machiavellian aspect of propaganda, in which the audience is subjected to a subtle and coarse, long-term or short-term process.

In this analogy of concepts, the integrative model offered by Garth Jowett and Victoria O'Donnell is recommended:

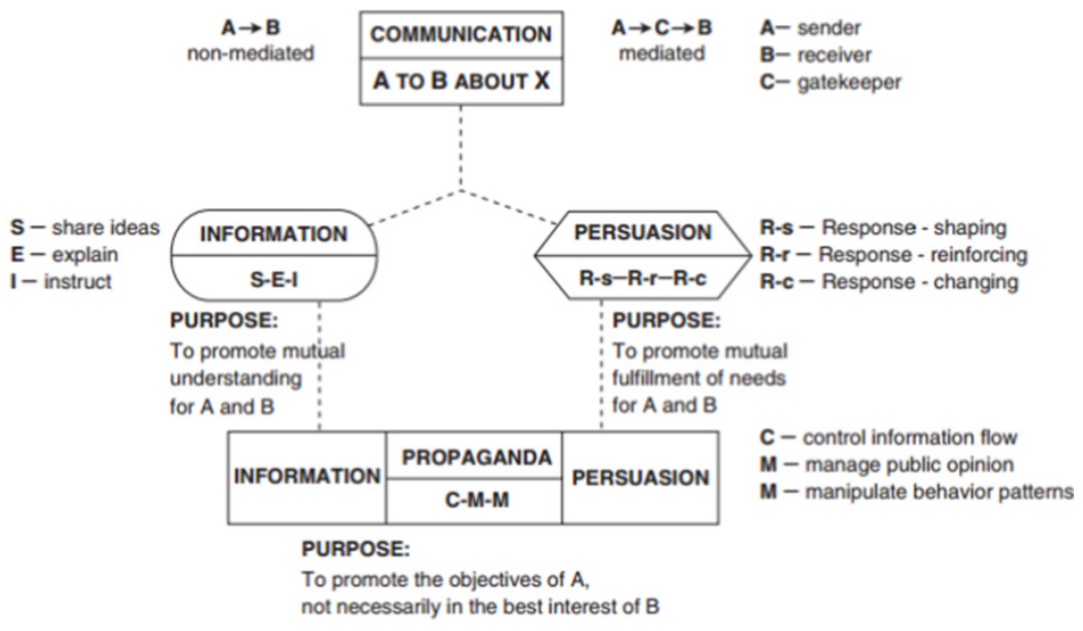

Purpose: promoting A's goals, not necessarily for B's interests.

Figure no. 3 The integrative model

(Source: O'Donnell \& Jowett, 2012, p. 29) 
These authors associate propaganda with mass persuasion as a global social process, while the concept of persuasion is regarded as an individual or inter-individual psychological process. Persuasion presupposes the ability of the transmitter to deliver to the receiver grounds for reconsidering his/her own ideas and beliefs in order to change and restructure them, rationally or emotionally. The act of persuasion involves creating the answer. The success of persuasion depends on what every persuasive agent believes about himself, "any persuasion involves self-persuasion" (Albu, 2008, p. 83). Misinformation is another very close concept and often used by propaganda. Misinformation is the tool that distorts the conversational target by subtle and secret methods, changing the perception of reality. This concept blends perfectly with manipulation and subversion, so they are often used by secret services or military commanders in war.

In conclusion, propaganda uses techniques that belong to other concepts to achieve its goals. Persuasion is the closest to manipulation, just as propaganda is sometimes mistakenly associated with misinformation. In communicative situations they intertwine. Manipulation involves persuasion, but it is important to specify that persuasion does not have the same negative connotation as manipulation. Because in the manipulation of the interlocutor, the recipient of the message is not aware of the source's intentions, the receiver's, and thus does not realize that it is influenced. While in the act of persuasion, we are aware of the influence and we accept it with conviction. Manipulation has become synonymous with misinformation, it is generally assimilated "as a glum machinery, as a guilty activity designed to disturb opinions in favor of unrealistic interests, as a perversion of the information process" (Rotaru, 2005, p. 164).

\section{Implications of propaganda on social networks}

Today we are dealing with a modern propaganda that is very present in the virtual space thanks to the new media technologies (satellite television, the Internet), which ensure a rapid transmission of information.

In today's society, most people have a divisive Smartphone with fast internet access as an extension of their own reason, which breaks the boundaries of the real space, bringing people closer to their distances. The Internet is a global element in communication. Virtual Reality subverts physical reality. It is the most accessible means of rapid and direct transmission of information to the general public. Thus, social networks in the virtual environment have transformed the internet into a propaganda vector of individuals susceptible to be the origin of radicalization and terrorist recruitment of jihadist inspiration, such as Facebook, Dailymotion or Twitter, allowing the broadcast of images that can change the world or engage in interventions at certain hot spots of the globe (Erhan, 2014).

The security of a state depends on the perception and adaptation of the population to threats and risks. In this sense, modern propaganda distorts the perception of the population through disinformation with the help of new technologies, causing a large phenomenon. Given the decline in public confidence in political leaders and state institutions, propaganda is active and aggressive in the online environment, with a negative effect on the collective mentality. These feelings of mistrust, weakness, disappointment, instability, develop a sensitive and vulnerable individual, directing him/her indirectly to certain groups of interest (Domenach, 2004, p. 12). Such an individual is the target of any propaganda. 
Thus, the information messages spread on media channels are predominantly negative, incisive, destabilizing and described by suggestive images that give rise to unexpected, emotional or violent reactions. Modern propaganda action in social media requires a careful analysis of the individual and the target group, of the mass influences. Information and ideas broadcast on or outside a state have the power to destabilize the state and to address national security. Nowadays, due to the propaganda (aggressive or concealed) in the online environment, more and more states face instability, insecurity, terrorist attacks and criminality. Given that information is large and diverse, perceptions and directions are created and directed on social networks. It is necessary to make the public opinion aware of the materials provided by the online space, to analyze them carefully and seriously. It is necessary to verify the credibleness of the information and of the issuers. This issue is a current issue and concerns the political environment, because it recognizes the impact and power of manipulating social networks (Facebook, Twitter and Instagram) on the collective mentality.

There are many examples of manipulating and spreading propaganda on the population through social networks that have triggered riots, demonstrations, or even political changes in a state.

The Panama Papers case, in which Russian companies invested in Facebook and Twitter, demonstrates the Russian interest in the American social media online. Later, Russia was accused of a possible misinformation campaign in the online environment that favored a certain candidate for the White House. Afterwards, a Twitter representative admitted that Russia Today was a propaganda tool of Russia and was sponsored with a considerable amount of dollars.

Another example is the Arab Spring 2010 phenomenon, when protests took place in countries in the Middle East and North Africa, especially in Arab countries with an authoritarian and totalitarian regime. Modern communication tools such as Facebook or Twitter have prompted the population to revolt, which is why governments in affected countries have blocked citizens' access to them and the internet. Similarly, the access of international media to these states has been restricted; the journalists from $\mathrm{CNN}$, Al Jazeera in the field have been threatened or even subjected to violence.

Terrorist groups are aware of the usefulness of the Internet and use it in the pursuit of black, jihadist propaganda. They collect data and information in the preparation of future actions. They also use the internet and the media to spread fear and intimidation, claim and instigate attacks, increasing global insecurity. Their online publications are written in several languages and are accessible at a click away. Their presence with a large number of Facebook and Twitter accounts demonstrates their interest in promoting black propaganda through materials posted among young people. The main form of recruitment of the new sympathizers of the Islamic state of Europe has been created through social networks.

In conclusion, propaganda through platforms and social networks can be a determining factor in the security of sovereign states by influencing the population, especially young people, for beneficial purposes, such as the Arab Spring, when the population mobilized and influenced to escape a pressure from the totalitarian regime. We can say that the social networks have succeeded with the help of free alibi white propaganda to encourage the desire for freedom and affirmation by the power of example.

At the same time, propaganda can also have negative effects through social networks through which they spread messages to incite hatred, violence, rebellion and anarchism. Taking advantage of an increasing number of social network users, terrorist groups are trying to propagate their messages and extremist 
views among marginalized, recidivists and radical-minded individuals. Daesh is the ideal example of extremist propaganda in the virtual environment that uses all the means of this social influence strategy to gain followers from all corners of the world.

\section{Conclusions}

In conclusion, the implications of propaganda are multiple, both positive and negative, it is very important how information is managed. Misinformation plays a strategic role in achieving certain hidden goals. Regarding this phenomenon of social influence, George Orwell draws attention to the doublethink concept in which he underlined the antinomic relationship between thinking and speech. The double language is used in the propaganda and war speech to influence public opinion behavior and transform it into a vector of pressure.

There is an increase in the role of the media and the fast communication techniques in society, due to the interest of the public. But the major importance of the ability to discern between correct information, publicity and manipulation needs to be considered. Absence of information or uncontrolled information amplifies the crisis/conflict. Thus, control of information and reality is very important in a democratic society.

\section{REFERENCES}

Albu, G. (2008). Comunicarea interpersonală. Iași: European Institute Publishing House.

David, M. (2018). Propaganda digitală şi securitatea naţională, available at: http://intelligence.sri.ro/propaganda-digitala-si-securitatea-nationala/, accessed on 13 December 2018.

Domenach, J.H. (2004). Propaganda politică. Iaşi: Editura Institutul European.

Ellul, J. (2008). Propagandes. Paris: Éditions Economica.

Erhan, I. (2014). Internetul ca spaţiu de exprimare a terorismului în serviciul jihadului, available at: https://dilemaveche.ro/sectiune/tema-saptamanii/articol/internetul-ca-spatiu-deexprimare-a-terorismului-in-serviciul-jihadului, accessed on 13 December 2018.

Gavreliuc, A. (2007). De la relaţiile interpersonale la comunicarea socială, available at: https://alingavreliuc.files.wordpress.com/2010/07/alin-gavreliuc-de-la-relatiile-interpersonalela-comunicarea-sociala-2007.pdf, accessed on 29 November 2018.

Hentea, C. (2008). Noile haine ale propagandei. Bucharest: Paralela 45 Publishing House.

Jowett, G. S. \& O'Donnell, V. (2012). Propaganda and persuasion available at: https://hiddenhistorycenter.org/wp-content/uploads/2016/10/PropagandaPersuasion2012.pdf, accessed on 29 November 2018.

Rotaru, N. (2005). Comunicarea în organizațiile militare. Bucharest: Tritonic Publishing House.

Shultz, R. H., \& Godson, R. (1984). Dezinformatsia: active measures in soviet strategy. Elmsford, N.Y.: Pergamon Press.

Smith, T. J. (1989). Propaganda: A Pluralistic Perspective. New York: Praeger Publishers.

Ţurlea, Ş. (2011). Călin Hentea: Confruntarea propagandistică dintre ideologii diferite este necesară pentru progresul societăţii, available at: https://www.zf.ro/ziarul-deduminica/calin-hentea-confruntarea-propagandistica-dintre-ideologii-diferite-este-necesarapentru-progresul-societatii-9021907, accessed on 29 November 2018. 